\title{
Resilience of aquatic net-spinning caddisfly silk structures to common global stressors
}

\section{Authors: Lindsey K. Albertson, and Melinda D. Daniels}

This is the peer reviewed version of the following article: [Albertson, Lindsey K., and Melinda D. Daniels. "Resilience of aquatic net-spinning caddisfly silk structures to common global stressors.." Freshwater Biology 61, no. 5 (May 2016): 670-679], which has been published in final form at https://dx.doi.org/10.1111/fwb.12737. This article may be used for non-commercial purposes in accordance with Wiley Terms and Conditions for Self-Archiving.

Made available through Montana State University's $\underline{\text { ScholarWorks }}$ scholarworks. montana.edu 


\title{
Resilience of aquatic net-spinning caddisfly silk structures to common global stressors
}

\author{
Lindsey K. Albertson* ${ }^{\dagger}$ and Melinda D. Daniels* \\ *Stroud Water Research Center, Avondale, PA, U.S.A. \\ ${ }^{\dagger}$ Department of Ecology, Montana State University, Bozeman, MT, U.S.A.
}

\section{SUMMARY}

1. Two of the most common consequences resulting from land use and climate change are increased fine sediment loads and shifts in hydrological regimes in freshwater ecosystems.

2. Although a growing number of studies indicate that these stressors are likely to directly affect community composition and organism physiology, little is known about how biological structures produced by aquatic organisms might respond. For example, hydropsychid caddisflies (Trichoptera) are a group of globally distributed aquatic insects that spin silk mesh nets that they use to filter feed. These silk mesh nets are important ecosystem engineering structures in flowing waters that can regulate sediment erosion, food particle delivery by altering near-bed current velocities, and enhance habitat availability for other macroinvertebrates.

3. We conducted two experiments in laboratory mesocosms to assess the effects of increased fine sediment and drought on hydropsychid caddisfly silk. We compared silk thread diameter, thread count, mesh pore area, and thread tensile strength across treatments in which the silk nets were exposed to high levels of total suspended solids or to stream drying over 2 weeks.

4. We found that caddisfly silk was resilient to both forms of stress and maintained its overall structure and tensile strength.

5. Our findings indicate that biological silk structures may be viable ecosystem engineering tools following short-lived disturbances associated with increased sediment loads and drying events. Caddisfly silk may be resilient to various forms of environmental change, with important consequences for recovery of aquatic communities.

Keywords: desiccation, drought, ecosystem engineers, global change, total suspended solids

\section{Introduction}

From climate warming to the introduction of invasive species, anthropogenic influences are initiating shifts in species interactions, population densities and timing of organismal development in freshwater ecosystems (Lodge et al., 2000; Musolin, 2007; Palmer et al., 2008). Two of the most globally common changes include increased fine suspended sediment loads and altered hydrological regimes (Richter et al., 1997), which are important variables that structure stream ecosystems (Allan, 1995; Dodds \& Whiles, 2010). Urban and agricultural land use plays a major role in controlling suspended sediment (Jordan \& Vaas, 2000), and river networks are experiencing an increase in suspended sediment loads
(Syvitski et al., 2005). Changes to hydrology resulting from climate warming and land cover alteration are also prevalent in freshwater ecosystems (Spinello \& Simmons, 1992; Palmer et al., 2008). Water stress related to timing and severity of drought conditions and stream intermittency are predicted to increase globally across many stream types (Stewart, Cayan \& Dettinger, 2005; Dai, 2011). In the light of these changes to sediment loads and flow, studies that integrate the disciplines of ecology and geomorphology to investigate feedbacks between sediment, hydrology, and freshwater organisms have become increasingly common (Palmer \& Bernhardt, 2006; Viles et al., 2008; Allen, Cardinale \& Wynn-Thompson, 2014).

Several synthesis papers now demonstrate the substantial influence that organisms can directly have on 
flow and physical transport processes related to sediment movement. For example, animals such as salmonid fish and plants such as Elodea (Hydrocharitaceae) waterweed can regulate current velocities, gravel movement and fine sediment suspension through bioturbation or by producing structures (Jones, 2012; Statzner, 2012). These types of organisms are often called ecosystem engineers and are described as maintaining, modifying, or creating physical habitat structure (Jones, Lawton \& Shachak, 1994). Recent efforts have begun to address the magnitude of ecosystem engineering effects as a result of biotic constraints such as organism density and abiotc constraints such as stream discharge and sediment size (Moore, 2006; Albertson \& Allen, 2015). However, despite the growing evidence that freshwater ecosystems are experiencing changes to sediment loads and hydrological regimes, we have only a preliminary understanding of how global change and ecosystem engineering effects interact (Lavelle et al., 1997; Crooks, 2002; Crain \& Bertness, 2006; Wright \& Jones, 2006; Reinhardt et al., 2010).

Hydropsychid caddisflies (Trichoptera) are a globally distributed group of net-spinning insects that live in the benthic substrate of most streams, where they secrete silk threads that are woven into a mesh net to catch food particles from the water column (Wiggins, 1977; Mackay \& Wiggins, 1979). Hydropsychid caddisflies act as ecosystem engineers in several ways. The filter-feeding habits of net-spinning caddisflies can regulate total seston transport (Georgian \& Wallace, 1981; Brown et al., 2005). Hydropsychid caddisflies create habitat for other macroinvertebrates such as mayflies with their silk net structures by reducing near bed currents and providing low-flow refuge space (Nakano, Yamamoto \& Okino, 2005). Their silk structures can also fundamentally alter sediment transport conditions, including sediment stability and flow currents (Statzner et al., 1999; Cardinale, Palmer \& Collins, 2002). By building their silk nets in pore spaces between and under gravels, caddisflies can bind gravels together and increase the force required to move sediments during a flood across a range of grain sizes (Johnson et al., 2009; Albertson, Cardinale \& Sklar, 2014a).

Net-spinning caddisflies may be strongly influenced by sediment levels and drought. Evidence suggests that some hydropsychid caddisfly species are sensitive to levels of suspended solids (Strand \& Merritt, 1997; Bonada et al., 2004), with high levels of suspended solids regulating the distribution and density of caddisfly populations (Dance \& Hynes, 1980). Changes in net-tending behaviours, including adjustment of silk threads and net cutting, have been shown to increase as suspended particle size and load increase (Runde \& Hellenthal, 2000). Hydropsychid caddisflies can survive for at least 1 week during drought conditions (Imhof \& Harrison, 1981) but are generally less abundant in streams that experience intermittent levels of flow (Grubbs, 2010). The architecture and arrangement of threads in caddisfly silk nets appears to be particularly responsive to metal pollutants, pesticides, and increased flow velocity (Petersen \& Petersen, 1983; Loudon \& Alstad, 1992; Balch et al., 2000; Tessier et al., 2000), but less is known about these silk net structures when exposed to changes in suspended sediment and drought conditions.

Here, we investigate the role of environmental stress on ecosystem engineering potential by assessing the impact of two common stressors, high fine sediment loads and stream drying, on silk structures produced by a common aquatic insect. We describe two independent experiments designed to assess the separate effects of sedimentation and drought on caddisfly silk structures. We used laboratory mesocosms to create chronically high levels of total suspended solids and a 2-week long stream-drying event in flumes where caddisflies had colonised sediment patches. We then measured the response of caddisfly silk to these stressors by quantifying changes to silk net architecture and silk tensile strength. Our findings provide some of the first evidence that caddisfly silk may be a biological structure that is resilient to various forms of human-mediated stress and may act as an agent of resistance and recovery for aquatic communities experiencing changes in sediment loads and hydrological regimes.

\section{Methods}

\section{Experimental setup}

To assess the impacts of increased suspended sediment levels and of drought on hydropsychid caddisfly silk, we conducted two, sequential experiments ('sediment experiment' and 'drought experiment') in replicate flumes at the Stroud Water Research Center in Avondale, PA. Each flume was $0.46 \mathrm{~m}$ wide $\times 10 \mathrm{~m}$ long $\times 0.16 \mathrm{~m}$ deep and housed in a greenhouse facility that receives a natural light regime. In each flume, water was supplied from nearby White Clay Creek and recirculated by a Baldor (Baldor Electric Company, Fort Smith, Arkansas, U.S.A) $1 / 4$ horsepower industrial motor pump. Flow velocity in each flume was held at $0.30 \mathrm{~m} \mathrm{~s}^{-1}$ and $0.12 \mathrm{~m}$ deep. Sediments were arranged with a subsurface layer with a median grain size of 
$15 \mathrm{~mm}$ covered by a surface layer with a median grain size of $50 \mathrm{~mm}$. Caddisflies in the family Hydropsychidae were collected by hand from White Clay Creek, which contains several documented genera of caddisfly. As it can be challenging to identify caddisflies without the use of a microscope, caddisflies in the sediment experiment (described next) were preserved and identified to genus or species after the experiment had been completed.

\section{Sediment experiment}

To evaluate the effects of suspended sediment on caddisfly silk mesh structures, an experiment was run from 2 June to 20 June 2014. Caddisflies were introduced to each of 10 flumes at a density of $1000 \mathrm{~m}^{-2}$ (230 individuals per flume) in a working patch of sediment located $8 \mathrm{~m}$ from the flume entrance and $1.5 \mathrm{~m}$ from the flume end that was $0.46 \mathrm{~m}$ wide $\times 0.5 \mathrm{~m}$ long. This density was selected to be in the common range of densities in the $1000 \mathrm{~s} \mathrm{~m}^{-2}$ that has been measured in similar streams in the mid-Atlantic region (Cardinale, Gelmann \& Palmer, 2004). Caddisflies were allowed 7 days to colonise sediments and construct their silk mesh nets. Treatments were categorised as either low or high total suspended solids (TSS) levels. In the high TSS treatments ( $n=5$ flumes), we supplemented the gravel matrix with fine sediment collected from White Clay Creek that was first passed through a $355 \mu \mathrm{m}$ sieve to remove sands. The low TSS treatments ( $n=5$ flumes) did not receive additional sediment. We aimed for levels of high TSS to be within the range of $100 \mathrm{mg} \mathrm{L}^{-1}$ to represent commonly experienced levels of TSS during high flow events or runoff from land with close proximity to agriculture (Ahearn et al., 2005; Wohl \& Carline, 2011). As some sediment in the high TSS treatment settled out into the gravels over the course of several hours, we vigorously disturbed all gravels upstream of the working patch where caddisflies were located twice per day for 14 days over the duration of the experiment. This physical disturbance was carried out in both high and low treatments to maintain consistency and did not physically alter the portion of the flume where caddisfly silk nets were constructed. TSS samples were taken once per day in both high and low treatments by sampling $1 \mathrm{~L}$ of water. Samples were filtered through a $45 \mu \mathrm{m}$ mixed cellulose ester membrane, dried at $60{ }^{\circ} \mathrm{C}$ for $24 \mathrm{~h}$, and weighed to estimate total suspended solids as $\mathrm{g} \mathrm{L}^{-1}$. Water temperature averaged $19.0^{\circ} \mathrm{C}$ over the course of the experiment. We estimated benthic sediment accumulation within the sediment patches where caddisflies were located in both high and low treatments at the end of the experiment by scraping the surface of a $4 \times 4 \mathrm{~cm}$ section of three $40 \mathrm{~mm}$ diameter grains, homogenising the sample, filtering the sample through a $45 \mu \mathrm{m}$ mixed cellulose ester membrane, drying the sample at $60^{\circ} \mathrm{C}$ for $24 \mathrm{~h}$, and weighing the sample to estimate $\mathrm{g} \mathrm{cm}^{-2}$. Upon completion of the experiment, we sampled and processed silk nets using the method described in the section below titled 'Caddisfly silk net measurements.' Individual caddisfly larvae were sampled and preserved in $90 \%$ ethanol until being identified, dried at $60{ }^{\circ} \mathrm{C}$ for $48 \mathrm{~h}$, and weighed to estimate body mass.

\section{Drought experiment}

To evaluate the impacts of drought on caddisfly silk mesh structures, a second, separate experiment was run from 7 July to 25 July 2014 after cleaning and resetting the gravels (50 mm surface layer covering a $15 \mathrm{~mm}$ subsurface layer) in 5 of the flume beds. Caddisflies were introduced to each of the five flumes at a density of $1000 \mathrm{~m}^{-2}$ (230 individuals per flume) in a working patch of sediment located $8 \mathrm{~m}$ from the flume entrance and $1.5 \mathrm{~m}$ from the flume end that was $0.46 \mathrm{~m}$ wide $\times 0.5 \mathrm{~m}$ long. Caddisflies were allowed 7 days to construct silk nets. We then eliminated flow completely for 14 days to simulate a drought for $n=3$ flumes. The control treatments $(n=2)$ maintained running water for this 14-day drought period. After 14 days, we reintroduced water to the dry flumes by slowly ramping up flow to the same level as in the controls $\left(0.3 \mathrm{~m} \mathrm{~s}^{-1}\right)$ over the course of $30 \mathrm{~min}$. Although it is possible that the force of water being reintroduced to a previously dried stream may break the silk threads, the rate and velocity of water flow entering a stream channel following drought is not well understood (Lake, 2011). This experiment was designed to measure the architecture and strength of nets that were still intact after drought and was not meant to represent the response of silk following a large-scale, high discharge, rewetting event. After $24 \mathrm{~h}$ of rewetting, we sampled silk nets from all flumes using the method described in the next section ('Caddisfly silk net measurements'). Water temperature in the control treatments averaged $21.2{ }^{\circ} \mathrm{C}$ over the course of the experiment.

\section{Caddisfly silk net measurements}

We quantified silk net architecture in both experiments by measuring thread count, thread diameter, pore size and silk thread tensile strength. We sampled as many 
nets as we were able to successfully harvest from each flume without breaking the silk structure during the sampling effort (c. 30 nets per flume). Broken net samples were eliminated from further analysis. Individual nets were held in 50\% ETOH until processing and for no more than 5 days. We mounted each net on a microscope slide and used an Olympus BZ61 microscope with a Sony Exwave HAD digital camera to capture pictures of each net. We calculated thread count per mm, average thread diameter of three representative threads, and average pore area of two representative mesh pores. We then used an ESM-301automated test stand (Mark-10, Long Island, New York, U.S.A) with a 10 Newton (N) load cell attached to a M5-2 force gauge to measure silk strength. Nets were pulled on at a rate of $30 \mathrm{~mm} \mathrm{~s}^{-1}$ for $4 \mathrm{~s}$ and average force was recorded. The trigger setting to initiate measurement of tensile force on the force gauge in the sediment experiment was $0.01 \mathrm{~N}$ and $0.008 \mathrm{~N}$ for the drought experiment. Measurements of net architecture were used to calculate silk thread strength as $\sigma=\frac{F_{C}}{N_{T} A}$ where $\sigma$ is thread tensile strength, $F_{C}$ is the force of the full sample (including multiple threads), $N_{T}$ is the number of threads in tension, and $A$ is the cross-sectional area of a thread (Albertson et al., 2014b).

\section{Data analysis}

To assess the effectiveness of the experimental manipulation, sediment levels were compared in the fine sediment experiment using a mixed effects linear model with total suspended solids (TSS) or benthic sediment accumulation as a fixed effect of treatment (high versus low) and the random effect of flume. Individual caddisfly weight was compared across high and low TSS treatments to test for effects of sediment load on caddisfly food consumption using a linear mixed effects model with individual weight as a fixed effect of treatment and the random effect of flume. Silk net characteristics were compared across treatments using a linear mixed effects model where thread count, thread diameter, pore area or thread tensile strength was a function of the fixed effect of treatment (high versus low) and the random effect of flume.

In the drought experiment, silk net characteristics were compared across treatments using a linear mixed effects model where thread count, thread diameter, pore area or thread tensile strength was a function of the fixed effect of treatment (wet versus dry) and the random effect of flume. All analyses were performed in $\mathrm{R}$ 3.2.2 (R Development Core Team, 2008) using the nlme package (Pinheiro et al., 2015) and lme function.

\section{Results}

We were able to successfully achieve a high TSS treatment in the sediment experiment. Suspended sediment levels were 10x higher in treatments with high versus low TSS levels $(t=-10.86, P<0.001)$, averaging 72.8 and $7.4 \mathrm{mg} \mathrm{L}^{-1}$ for high and low treatments respectively. Accumulated benthic sediments levels were $3.5 x$ higher in high TSS treatments, averaging 4.8 and $1.3 \mathrm{mg} \mathrm{cm}^{-2}$ for high and low treatments, respectively. After identifying caddisflies in the sediment experiment, we found that the caddisfly assemblage in White Clay Creek was dominated by Hydropsyche betteni (90\%), while Hydropsyche sparna (5\%), Hydropsyche slossinae (2\%), Cheumatopsyche spp. (2\%), and Diplectrona spp. (1\%) were much less common. Subsequent data analysis pooled silk net characteristics across all species for both experiments.

We compared silk net characteristics across treatments in both experiments to assess the impacts of sediment loads and stream drying on the silk structure. Net architecture was not different across treatments with highversus low-TSS treatments (Fig. 1a). Thread count $(t=0.084, \quad P=0.428)$, thread diameter $(t=-1.828$, $P=0.105)$ and pore area $(t=-1.613, P=0.108)$ were all consistent across treatments. In high TSS treatments, thread count averaged $18.23 \pm 0.42 \mathrm{~mm}^{-2}$, thread diameter averaged $10.51 \pm 0.16 \mu \mathrm{m}$, and pore area averaged $0.022 \pm 0.001 \mathrm{~mm}^{2}$, and in low TSS treatments thread count averaged $18.93 \pm 0.42$, thread diameter averaged $9.70 \pm 0.18$, and pore area averaged $0.020 \pm 0.001$. Larval caddisfly weight was not different across treatments of suspended sediment loads (Fig. 1b; $t=-0.835$, $P=0.428$ ), averaging $0.0065 \pm 0.0002 \mathrm{~g}$ in dry treatments and $0.0060 \pm 0.0002$ in wet treatments, suggesting individuals from both treatments were eating similar amounts of food.

Most characteristics of net architecture were consistent in dry versus control treatments in the drought experiment (Fig. 1a). Thread count $(t=-2.00, P=0.139)$ and thread diameter $(t=-0.668, P=0.552)$ were not different across dry and wet treatments. In dry treatments, thread count averaged $16.11 \pm 0.75 \mathrm{~mm}^{-2}$ and thread diameter averaged $6.89 \pm 0.14 \mu \mathrm{m}$. In wet treatments, thread count averaged $18.28 \pm 0.67 \mathrm{~mm}^{-2}$ and thread diameter averaged $7.02 \pm 0.16$. However, pore area was marginally larger for dry nets, averaging $0.031 \pm 0.003 \mathrm{~mm}^{2}$ in dry treatments and $0.019 \pm 0.001$ in wet treatments, suggesting that the silk material may have stretched out during the drying process $(t=2.824, P=0.067)$. Despite introducing 230 caddisflies to each of the flumes $\left(1000 \mathrm{~m}^{-2}\right)$, 


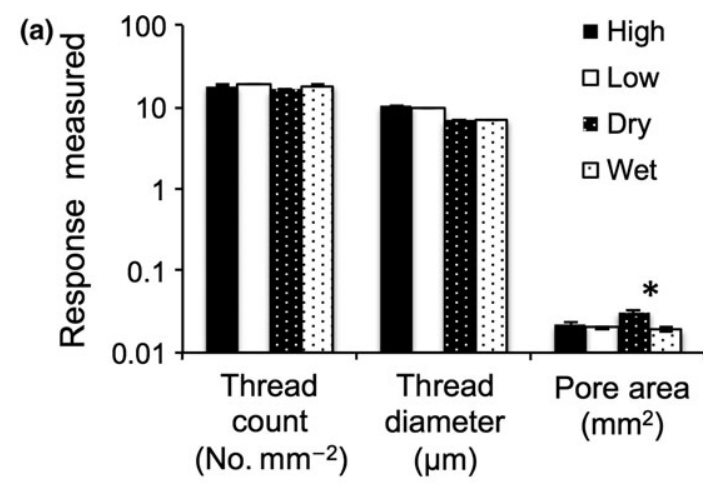

(b)

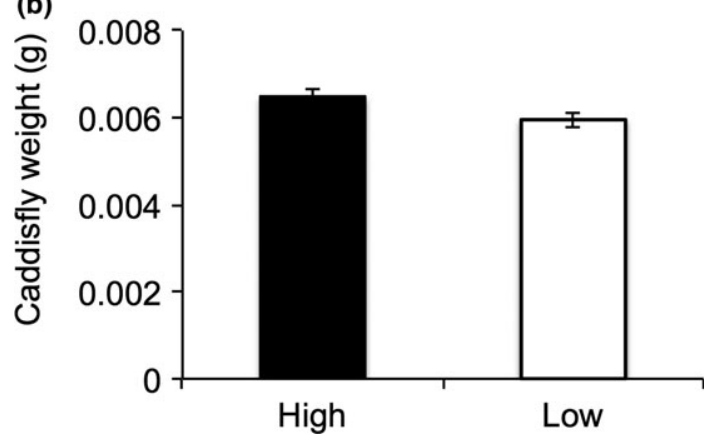

Fig. 1 Silk net characteristics in the sediment and drought experiment. (a) No differences among thread count, thread diameter or pore size in the sediment experiment were detected. Values are means $\pm 1 \mathrm{SE}$ for $n=113$ nets for high TSS treatments and $n=106$ nets for low TSS treatments. Thread count and diameter were similar among dry and wet (control) treatments. Pore size was marginally larger in dry treatments $(P=0.067)$. Values are means $\pm 1 \mathrm{SE}$ for $n=29$ for wet treatment nets and $n=45$ dry treatment nets. Asterisk indicates significance at $P \leq 0.01$. (b) Individual caddisfly weight in the sediment experiment. No differences in caddisfly body size were detected across treatments. Values are means \pm 1 SE.

only 2 caddisflies were found alive across all dried flumes at the end of the 14-day drought treatment, indicating that drought had a substantial and direct negative impact on these aquatic insects. However, the silk visually looked similar and maintained its integrity even after being dry for 14 days (Fig. 2).

No differences in tensile strength were detected after the silk had been exposed to the two forms of environmental stress. Silk tensile strength was not different between high and low sediment levels (Fig. 3a; $t=-0.044, P=0.966)$, averaging $4.6 \pm 0.5$ MegaPascals and $4.5 \pm 0.4$, respectively. Silk strength was also maintained in the drought experiment. Although pore space was larger in dry treatments and suggested the silk may have been stretched, we found no evidence for a reduction in silk strength between dry and wet treatments (Fig. 3b; $t=0.169, P=0.877$ ), averaging $8.3 \pm 0.8 \mathrm{MPa}$ and $8.1 \pm 0.8$, respectively.
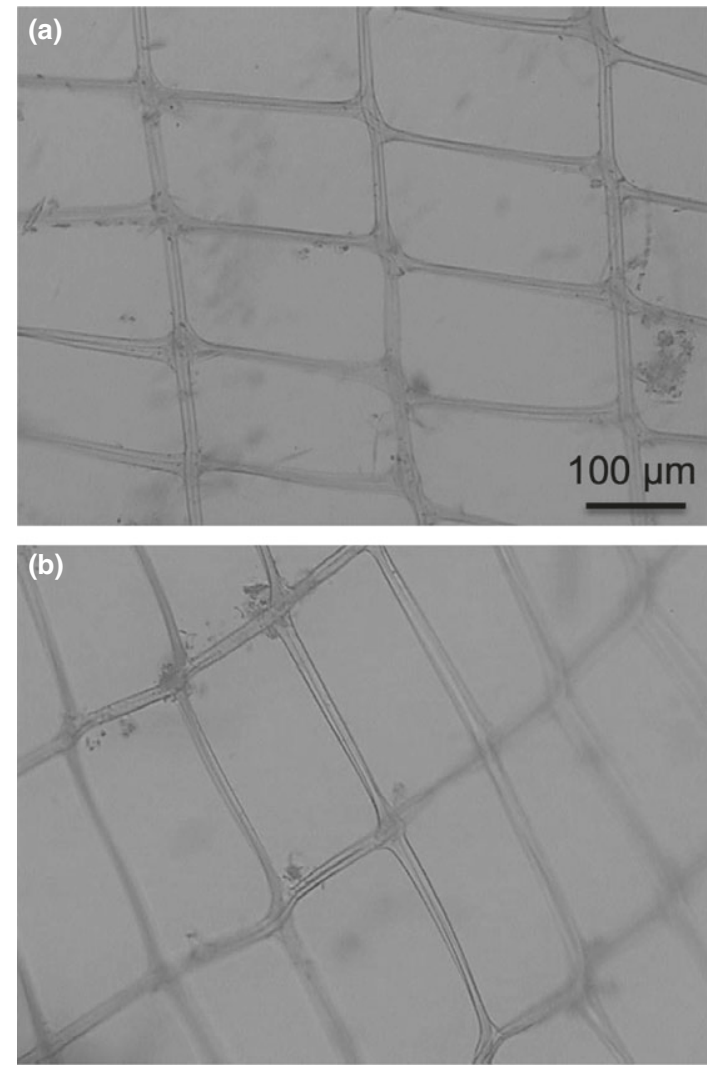

Fig. 2 Visual similarities among nets from (a) control (wet) treatments and (b) 14-day dry treatments indicated that silk structure was maintained even after the nets were dry for 14 days.

\section{Discussion}

We have demonstrated that caddisfly silk is a biological material that can be resilient to environmental stress induced by sedimentation and stream drying. We detected no differences in characteristics used to quantify silk net architecture across levels of high versus low sediment loads and dry versus wet conditions. Mesh pore size in the dry treatments was marginally larger than in wet treatments, but the silk threads maintained their tensile strength despite being slightly stretched. Although other forms of stress such as pollutants have been shown to alter body morphology of some macroinvertebrates and change the architecture of caddisfly silk nets, sediment loads and drought did not appear to alter the ability of hydropsychid caddisflies to construct nets (Hamilton \& Saether, 1971; Donald, 1980; Petersen \& Petersen, 1983). Caddisfly silk threads can increase the force needed to move gravels, provide habitat for other macroinvertebrates, and regulate seston levels, and by using silk net architecture and tensile strength as a proxy for engineering potential our findings suggest that these effects may be maintained even in the face of short 


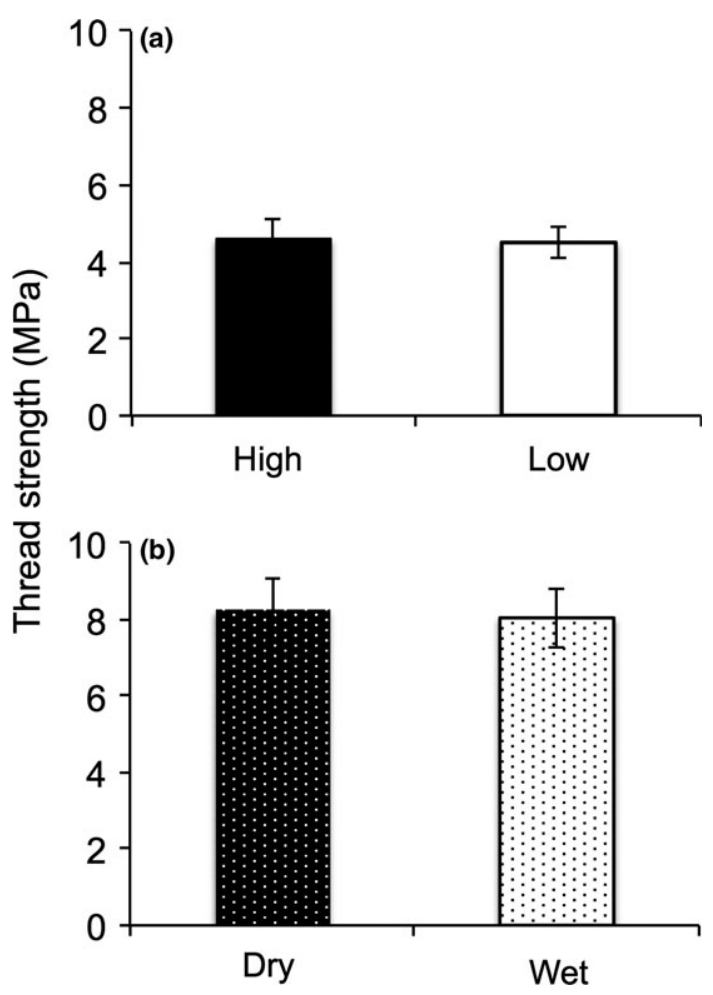

Fig. 3 Silk net tensile strength in the two experiments. (a) Silk thread strength (megapascals) was not different between treatments with high and low sediment loads. For $n=113$ for high and $n=87$ for low treatments. (b) Silk thread strength was not different between dry and wet treatments. Values are means $\pm 1 \mathrm{SE}$ for $n=29$ for control treatment nets and $n=45$ dry treatment nets.

disturbances induced by sedimentation and drought (Statzner et al., 1999; Johnson et al., 2009; Albertson et al., 2014b).

We found that increased sediment loads contacting the caddisfly mesh structures neither altered the silk architecture nor the eating behaviours and body mass of the caddisflies. However, a large number of studies have highlighted the negative influence of increased sediment loads on communities and populations of aquatic organisms. High levels of suspended sediments can drive increased drift rates of macroinvertebrates and alter behaviours of fish (Berg \& Northcote, 1985; Doeg \& Milledge, 1991). Increased levels of TSS typically reduce macroinvertebrate population abundance, although some filter-feeding caddisflies may increase in density, potentially due to an increased availability of food (Lenat, 1984; Wohl \& Carline, 2011). Major drivers of changes in sediment loads include urbanization and agricultural land use (Ahearn et al., 2005; Wohl \& Carline, 2011), and levels of TSS 3-5x higher than were used in this experiment have been regularly been documented in natural streams. Future research might investigate the abrading or clogging power of higher levels of TSS to caddisfly silk net material.

Changes to flow regimes also affect benthic aquatic communities, and our understanding of benthic community response across a gradient of drought duration is poorly developed (Muehlbauer, Doyle \& Bernhardt, 2011). Water levels can regulate drift rates, density, competition and mortality among macroinvertebrates (Feminella \& Resh, 1990; Bond \& Downes, 2000, 2003). In addition, drought conditions have been shown to drive shifts in species interactions, availability of food resources, and adaptations for surviving low flow conditions (Peterson, 1987; Lake, 2003). The glands that produce caddisfly silk can show differences in tensile strength and elongation potential in wet and dry states (Tsukada et al., 2010), but we detected minimal differences in silk thread characteristics under wet versus dry conditions in this study. Free-living caddisfly populations are particularly sensitive to drought conditions and typically recruit poorly the year after drought (Boulton, 2003). Trichoptera richness is negatively correlated with increasing discharge fluctuations associated with increasing drought in freshwater springs (Erman \& Erman, 1995; ), and different hydropsychid species may have differential tolerances and abilities to maintain water balance, feeding strategies and survival under low flow conditions (Yoder et al., 2015). Other caddisfly families that are not free-living but that use silk to build cases may be more tolerant of drying (Boulton, 2003; Power, Parker \& Dietrich, 2008; Brand \& Miserendino, 2014), but we are unaware of any studies that have investigated the structural changes or silk properties of cases built by caddisflies when stressed by drought. Free-living caddisflies may drift or accelerate development to avoid drought conditions, but in doing so, their silk structure may be left behind. Our experiment supports findings from other studies indicating that periods of drought on the order of weeks can directly reduce macroinvertebrate abundance or force macroinvertebrates to move to refuge spaces (Boulton, 2003) and further suggest that responses of macroinvertebrates that produce silk feeding structures may be more complex if those silk structures are viable even after being abandoned.

Silk thread strength was not different after being exposed to high sediment loads or drought, suggesting that silk structures may provide lasting engineering impacts on physical habitat structure in streams. Many stream organisms produce structures that affect sediment transport, flow currents, and disturbance regimes, including macrophytes and biofilm (Fritz \& Feminella, 
2003; Arnon et al., 2009), but little is known about how the influence of these organisms may also shift with global stressors. Blackfly silk has been shown to speed up secondary recovery (Hammock \& Bogan, 2014) and caddisfly silk can provide habitat for mayflies (Nakano et al., 2005). Chironomids also use silk to stabilise sediments (Edwards, 1962). The role of silk as a recovery mechanism and the influence on succession, one of the most important processes in ecosystems subjected to disturbance, remains to be explored (Connell \& Slatyer, 1977). Future experiments documenting the effects of caddisfly silk on riverbed gravel stability and the recovery of benthic biofilm and mayfly communities across a gradient in drought duration and TSS levels are an obvious next step.

Our study is inherently limited in its spatial and temporal scale, and extrapolations to the field should be made with caution. Flumes have been used in scientific studies for decades, and while they provide controlled experimental conditions, they simplify the considerable heterogeneity in velocity and sediment characteristics that exists in natural ecosystems (Vogel \& LaBarbera, 1978; Nowell \& Jumars, 1987). Our studies were conducted over relatively short time scales on the order of weeks, and as such, may provide only preliminary insight into effects of chronic sediment loading or drought on caddisfly silk. In addition, the two experiments reported in this study were conducted sequentially, and the observed differences in silk thread tensile strength between the two sequential experiments may be related to this temporal sequencing. The differences across experiments may have resulted from the progression through instar stage and thus body size of the caddisflies over the course of the month between experiments or from differences in silk thread structure or net architecture through the summer months. We are unaware of any studies that have investigated temporal variation in silk strength, but caddisflies are known to alter their net architecture with variation in seasonally relevant flow currents and with changes in body size through the growing season (Loudon \& Alstad, 1992; Willis \& Hendricks, 1992). Future work might consider parallel experiments to avoid temporal differences. Testing multiple, overlapping stressors within the same stream mesocosms would also reveal the nature of any interactive effects of these stressors on silk strength (Heugens et al., 2001).

In freshwater ecosystems, links between biology and physical habitat conditions are becoming increasingly important in the light of global changes to sediment loads and hydrological regimes (Palmer \& Bernhardt,
2006; Reinhardt et al., 2010). As a growing number of studies illustrate the importance of biotic engineers in freshwater ecosystems, understanding the role of these engineers in controlling nutrient cycling, sediment movement, and habitat structure in the face of global change is a critical next step for the field of ecogeomorphology (Statzner, 2012; Albertson \& Allen, 2015).

\section{Acknowledgments}

We thank Mike Broomall, Sarmistha Chatterjee, Dave Funk, John Jackson, Jennie Matkov, Will Milliken and Jonathan Spear at SWRC for field assistance, Jinjun Kan and Laura Borecki at SWRC for assistance with net architecture measurements, and two anonymous reviewers who provided comments on previous versions of this manuscript.

\section{References}

Ahearn D.S., Sheibley R.W., Dahlgren R.A., Anderson M., Johnson J. \& Tate K.W. (2005) Land use and land cover influence on water quality in the last free-flowing river draining the western Sierra Nevada, California. Journal of Hydrology, 313, 234-247.

Albertson L.K. \& Allen D.C. (2015) Meta-analysis: abundance, behavior, and hydraulic energy shape biotic effects on sediment transport in streams. Ecology, 96, 1329-1339.

Albertson L.K., Cardinale B.J. \& Sklar L.S. (2014a) Species interactions generate non-additive increases in sediment stability in laboratory streams. PLoS ONE, 9, e103417.

Albertson L.K., Sklar L.S., Pontau P., Dow M. \& Cardinale B.J. (2014b) A mechanistic model linking insect (Hydropsychidae) silk nets to incipient sediment motion in gravel-bedded streams. Journal of Geophysical ResearchEarth Surface, 119, 1833-1852.

Allan J.D. (1995) Stream Ecology: Structure and Function of Running Waters. Springer, New York.

Allen D.C., Cardinale B.J. \& Wynn-Thompson T. (2014) Towards a better integration of ecological principles into interdisciplinary ecogeoscience research. BioScience, 64, 444-454.

Arnon S., Marx L.P., Searcy K.E. \& Packman A.I. (2009) Effects of overlying velocity, particle size, and biofilm growth on stream-subsurface exchange of particles. Hydrological Processes, 24, 108-114.

Balch G.C., Evans R.D., Welbourn P. \& Prairie R. (2000) Weight loss and net abnormalities of Hydropsyche betteni (caddisfly) larvae exposed to aqueous zinc. Environmental Toxicology and Chemistry, 19, 3036-3043.

Berg L. \& Northcote T.G. (1985) Changes in territorial, gillflaring, and feeding behavior in juvenile coho salmon (Oncorhynchus kisutch) following short-term pulses of 
suspended sediment. Canadian Journal of Fisheries and Aquatic Sciences, 42, 1410-1417.

Bonada N., Zamora-Muñoz C., Rieradevall M. \& Prat N. (2004) Ecological profiles of caddisfly larvae in Mediterranean streams: implications for bioassessment methods. Environmental Pollution, 132, 509-521.

Bond N.R. \& Downes B.J. (2000) Flow-related disturbance in streams: an experimental test of the role of rock movement in reducing macroinvertebrate population densities. Marine and Freshwater Research, 51, 333-337.

Bond N.R. \& Downes B.J. (2003) The independent and interactive effects of fine sediment and flow on benthic invertebrate communities characteristic of small upland streams. Freshwater Biology, 48, 455-465.

Boulton A. (2003) Parallels and contrasts in the effects of drought on stream macroinvertebrate assemblages. Freshwater Biology, 48, 1173-1185.

Brand C. \& Miserendino M. (2014) Biological traits and community patterns of Trichoptera at two Patagonian headwater streams affected by volcanic ash deposition. Zoological Studies, 53, 72.

Brown S.A., Ruxton G.D., Pickup R.W. \& Humphries S. (2005) Seston capture by Hydropsyche siltalai and the accuracy of capture efficiency estimates. Freshwater Biology, 50, 113-126.

Cardinale B.J., Gelmann E.R. \& Palmer M.A. (2004) Net spinning caddisflies as stream ecosystem engineers: the influence of Hydropsyche on benthic substrate stability. Functional Ecology, 18, 381-387.

Cardinale B.J., Palmer M.A. \& Collins S.L. (2002) Species diversity enhances ecosystem functioning through interspecific facilitation. Nature, 415, 426-429.

Connell J.H. \& Slatyer R.O. (1977) Mechanisms of succession in natural communities and their role in community stability and organization. The American Naturalist, 111, 1119-1144.

Crain C.M. \& Bertness M.D. (2006) Ecosystem engineering across environmental gradients: implications for conservation and management. BioScience, 56, 211-218.

Crooks J.A. (2002) Characterizing ecosystem-level consequences of biological invasions: the role of ecosystem engineers. Oikos, 97, 153-166.

Dai A. (2011) Drought under global warming: a review. WIREs Climate Change, 2, 45-65.

Dance K. \& Hynes H. (1980) Some effects of agricultural land use on stream insect communities. Environmental Pollution (Series A), 22, 19-28.

Dodds W. \& Whiles M. (2010) Freshwater Ecology: Concepts and Environmental Applications of Limnology, 2nd edn. Elsevier, Burlington.

Doeg T. \& Milledge G. (1991) Effect of experimentally increasing concentrations of suspended sediment on macroinvertebrate drift. Australian Journal of Marine and Freshwater Research, 42, 519-526.
Donald D. (1980) Deformities in Capniidae (Plecoptera) from the Bow River, Alberta. Canadian Journal of Zoology, 58, 682-686.

Edwards R. (1962) Some effects of plants and animals on the conditions in fresh-water streams with particular reference to their oxygen balance. International Journal of Air and Water Pollution, 6, 505-520.

Erman N. \& Erman D. (1995) Spring permanence, Trichoptera species richness, and the role of drought. Journal of the Kansas Entomological Society, 68, 50-64.

Feminella J.W. \& Resh V.H. (1990) Hydrologic influences, disturbance, and intraspecific competition in a stream caddisfly population. Ecology, 71, 2083.

Fritz K.M. \& Feminella J.W. (2003) Substratum stability associated with the riverine macrophyte Justicia americana. Freshwater Biology, 48, 1630-1639.

Georgian T. \& Wallace J. (1981) A model of seston capture by net-spinning caddisflies. Oikos, 36, 147-157.

Grubbs S.A. (2010) Influence of flow permanence on headwater macroinvertebrate communities in a Cumberland Plateau watershed, USA. Aquatic Ecology, 45, 185-195.

Hamilton A. \& Saether O. (1971) Occurence of characteristic deformaties in chironomid larvae of several Canadian lakes. Candian Entomologist, 103, 363-368.

Hammock B.G. \& Bogan M.T. (2014) Black fly larvae facilitate community recovery in a mountain stream. Freshwater Biology, 59, 2162-2171.

Heugens E., Hendriks A., Dekker T., van Straalen N. \& Admiraal W. (2001) A review of the effects of multiple stressors on aquatic organisms and analysis of uncertainty factors for use in risk assessment. Critical Reviews in Toxicology, 31, 247-284.

Imhof J.G.A. \& Harrison A.D. (1981) Survival of Diplectrona modesta banks (Trichoptera : Hydropsychidae) during short periods of desiccation. Hydrobiologia, 77, 61-63.

Johnson M.F., Reid I., Rice S.P. \& Wood P.J. (2009) Stabilization of fine gravels by net-spinning caddisfly larvae. Earth Surface Processes and Landforms, 34, 413-423.

Jones C.G. (2012) Ecosystem engineers and geomorphological signatures in landscapes. Geomorphology, 157, 7587.

Jones C.G., Lawton J.H. \& Shachak M. (1994) Organisms as ecosystem engineers. Oikos, 69, 373-386.

Jordan S. \& Vaas P. (2000) An index of ecosystem integrity for Northern Chesapeake Bay. Environmental Science $\mathcal{E}$ Policy, 3, S59-S88.

Lake P. (2003) Ecological effects of perturbation by drought in flowing waters. Freshwater Biology, 48, 1161-1172.

Lake P. (2011) Drought and Aquatic Ecosystems: Effects and Responses. Wiley-Blackwell Publishing Inc, Chichester.

Lavelle P., Bignell D., Lepage M., Wolters V., Ineson P., Heal O. et al. (1997) Soil function in a changing world: the role of invertebrate ecosystem engineers. European Journal of Soil Biology, 33, 159-193. 
Lenat D.R. (1984) Agriculture and stream water quality: a biological Evaluation of erosion control practices. Environmental Management, 8, 333-344.

Lodge D., Taylor C., Holdich D. \& Skurdal J. (2000) Nonindigenous crayfishes threaten North American freshwater biodiversity: lessons from Europe. Fisheries, 25, 7-19.

Loudon C. \& Alstad D.N. (1992) Architectural plasticity in net construction by individual caddisfly larvae (Trichoptera: Hydropsychidae). Canadian Journal of Zoology, 70, 1166-1172.

Mackay R.J. \& Wiggins G.B. (1979) Ecological diversity in Trichoptera. Annual Review of Entomology, 24, 185-208.

Moore J.W. (2006) Animal ecosystem engineers in streams. BioScience, 56, 237-246.

Muehlbauer J.D., Doyle M.W. \& Bernhardt E.S. (2011) Macroinvertebrate community responses to a dewatering disturbance gradient in a restored stream. Hydrology and Earth System Sciences, 15, 1771-1783.

Musolin D. (2007) Insects in a warmer world: ecological, physiological and life-history responses of true bugs (Heteroptera) to climate change. Global Change Biology, 13, 1565-1585.

Nakano D., Yamamoto M. \& Okino T. (2005) Ecosystem engineering by larvae of net-spinning stream caddisflies creates a habitat on the upper surface of stones for mayfly nymphs with a low resistance to flows. Freshwater Biology, 50, 1492-1498.

Nowell A. \& Jumars P. (1987) Flumes: theoretical and experimental considerations for simulation of benthic environments. Oceanography and Marine Biology, 25, 91112.

Palmer M.A. \& Bernhardt E.S. (2006) Hydroecology and river restoration: ripe for research and synthesis. Water Resources Research 42, W03S07.

Palmer M.A., Liermann C.A.R., Nilsson C., Florke M., Alcamo J., Lake P.S. et al. (2008) Climate change and the world's river basins: anticipating management options. Frontiers in Ecology and the Environment, 6, 81-89.

Petersen L.B.M. \& Petersen R.C. (1983) Anomalies in hydropsychid capture nets from polluted streams. Freshwater Biology, 13, 185-191.

Peterson C.G. (1987) Influences of flow regime on development and desiccation response of lotic diatom communities. Ecology, 68, 946-954.

Pinheiro J., Bates D., DebRoy S. \& Sarkar D. and R Core Team. (2015) Nlme: Linear and Nonlinear Mixed Effects Models. R Package Version 3.1-122. Available at: http:// CRAN.R-project.org $/$ package=nlme.

Power M.E., Parker M.S. \& Dietrich W.E. (2008) Seasonal reassembly of a river food web: floods, droughts, and impacts of fish. Ecological Monographs, 78, 263-282.

R Development Core Team (2008) R: A Language and Environment for Statistical Computing. Available at: www.Rproject.org.
Reinhardt L., Jerolmack D., Cardinale B.J., Vanacker V. \& Wright J. (2010) Dynamic interactions of life and its landscape: feedbacks at the interface of geomorphology and ecology. Earth Surface Processes and Landforms, 35, 78-101.

Richter B.D., Braun D.P., Mendelson M.A. \& Master L.L. (1997) Threats to Imperiled Freshwater Fauna. Conservation Biology, 11, 1081-1093.

Runde J. \& Hellenthal R. (2000) Effects of suspended particles on net-tending behaviors for Hydropsyche sparna (Trichoptera: Hydropsychidae) and related species. Annals of the Entomological Society of America, 93, 678-683.

Spinello A. \& Simmons D. (1992) Base flow of 10 southshore streams, Long Island, New York, 1976-85, and the effects of urbanization on base flow and flow duration. USGS Water Resources Investigations Report, 90-4205, 1-39.

Statzner B. (2012) Geomorphological implications of engineering bed sediments by lotic animals. Geomorphology, 157, 49-65.

Statzner B., Arens M.F., Champagne J.Y., Morel R. \& Herouin E. (1999) Silk-producing stream insects and gravel erosion: significant biological effects on critical shear stress. Water Resources Research, 35, 3495-3506.

Stewart I., Cayan D. \& Dettinger M. (2005) Changes toward earlier streamflow timing across western North America. Journal of Climate, 18, 1136-1155.

Strand R.M. \& Merritt R.W. (1997) Effects of episodic sedimentation on the net-spinning caddisflies Hydropsyche betteni and Ceratopsyche sparna (Trichoptera: Hydropsychidae). Environmental Pollution, 98, 129-134.

Syvitski J.P.M., Vorosmarty C.J., Kettner A.J. \& Green P. (2005) Impact of humans on the flux of terrestrial sediment to the global coastal ocean. Science, 308, 376-380.

Tessier L., Boisvert J.L., Vought L.B.-M. \& Lacoursière J.O. (2000) Anomalies on capture nets of Hydropsyche slossonae larvae (Trichoptera: Hydropsychidae), a potential indicator of chronic toxicity of malathion (organophosphate insecticide). Aquatic Toxicology, 50, 125-139.

Tsukada M., Khan M.M.R., Inoue E., Kimura G., Hun J., Mishima M. et al. (2010) Physical properties and structure of aquatic silk fiber from Stenopsyche marmorata. International Journal of Biological Macromolecules, 46, 54-58.

Viles H.A., Naylor L.A., Carter N.E.A. \& Chaput D. (2008) Biogeomorphological disturbance regimes: progress in linking ecological and geormorphological systems. Earth Surface Processes and Landforms, 33, 1419-1435.

Vogel S. \& LaBarbera M. (1978) Simple flow tanks for research and teaching. BioScience, 28, 638-643.

Wiggins G.B. (1977) Larvae of the North American Caddisfly Genera. Toronto University Press, Toronto.

Willis L. \& Hendricks A. Jr (1992) Life history, growth, survivorship, and production of Hydropsyche slossonae in Mill Creek, Virginia. Journal of the North American Benthological Society, 11, 290-303.

Wohl N.E. \& Carline R.F. (2011) Relations among riparian grazing, sediment loads, macroinvertebrates, and fishes 
in three central Pennsylvania streams. Canadian Journal of Fisheries and Aquatic Sciences, 53, 260-266.

Wright J. \& Jones C.G. (2006) The concept of organisms as ecosystem engineers ten years on: progress, limitations, and challenges. BioScience, 56, 203-209.

Yoder J.A., Benoit J.B., Nelson B.W., Main L.R. \& Bossley J.P. (2015) Behavioral correction to prevent overhydration and increase survival by larvae of the net-spinning caddisflies in relation to water flow. Journal of Experimental Biology, 218, 363-369.

(Manuscript accepted 21 January 2016) 